\title{
DOES FURROW IRRIGATION SYSTEM IMPROVE YIELD AND WATER USE EFFICIENCY OF KINNOW MANDARIN (CITRUS RETICULATA BLANCO)?
}

\author{
aAhmed Raza*, aImtiaz A. Warraich, bMuhammad A. Nawaz, aMuhammad Asim, aAbdul Aziz, cFareeha Shireen, \\ aMalik A. Rehman \\ a Citrus Research Institute, Sargodha, Pakistan. \\ ${ }^{b}$ Department of Horticulture, College of Agriculture, University of Sargodha, Sargodha 40100, Pakistan. \\ ${ }^{c}$ College of Horticulture and Forestry Sciences, Huazhong Agricultural University/Key Laboratory of Horticultural Plant \\ Biology, Ministry of Education, Wuhan430070, PR China.
}

\section{ART ICLE IN F O}

\section{Article history}

Received: July 12, 2020

Revised: November 20, 2020

Accepted: December 28, 2020

\section{Keywords}

Citrus reticulata Blanco

WUE

Yield

Water saving

Irrigation methods

\section{A B S T R A C T}

In Pakistan, orchards are irrigated using flood irrigation system that is considered sub-economical regarding water use efficiency. Considering the importance of natural water resources, there was a need to devise the method of applying irrigation water that would save water consumption, environmentally friendly and easily adopted by the growers. Thus, a research trial was conducted at Citrus Research Institute, Sargodha, Pakistan on 0.41 ha area of Kinnow mandarin. The total area was divided into two parts, half of the area was used for furrow irrigation system and the remaining half was used for flood irrigation system. Tensiometers were installed in the soil in furrow and flood irrigation system to assess the moisture condition in the soil. Irrigations were applied when tensiometer readings reached 40 centibars. The quantity of water used for irrigation was measured with a flume meter and then percentage of water saving was calculated. The study revealed that furrow irrigation system significantly improved the number of fruits per tree (1153), fruit yield (179.89 kg per plant) and juice percentage (48.38\%) compared with flood irrigation system where the number of fruits per tree were711, fruit yield was $110.61 \mathrm{~kg}$ per plant and juice percentage was $46.31 \%$. However, TSS/acidity ratio, and peel and rag percentage were not affected by the different irrigation systems. In furrow irrigation system 24 irrigations were applied per year with average water saving of $46.14 \%$ and water use efficiency (WUE) was $4.58 \mathrm{~kg} \mathrm{~m}^{-3}$ whereas in flood irrigation system average numbers of irrigations were 15 per year and WUE was $2.34 \mathrm{~kg} \mathrm{~m}^{-3}$ only. Therefore, furrow irrigation system is recommended for the citrus growers to improve the water use efficiency, yield and fruit quality of Kinnow mandarin.

\section{Corresponding Author: Ahmed Raza}

Email: usama.shahzad@hotmail.com

(C) The Author(s) 2020.

\section{INTRODUCTION}

Citrus is an important fruit and cultivated on a commercial scale across the world. The world citrus production is 146.60 million tons per annum. Citrus is the leading fruit of Pakistan; it is cultivated an area of
0.195 million ha with an annual production of 2.26 million tons. In Pakistan, Kinnow (Citrus reticulata Blanco) is the leading cultivars that shares nearly $95 \%$ of the total citrus fruits produced across the country. Kinnow mandarin crop is facing serious challenge of 
slow decline that is because of poor management practices such as irrigation, malnutrition, and lack of pruning. Due to rise in population, the demand for water, energy and food supply is likely to increase 40 $50 \%$ by 2050 (Nawaz et al., 2016). Water storage capacity of three water reservoirs of Pakistan (Tarbela, Mangla and Chashma) is 13.86-million-acre feet (MAF) and Pakistan has only 30 days water storage capacity. Average water flow is $137 \mathrm{MAF}$ that varies from 97 to 186 MAF, out of which $80 \%$ water flows in 100 days from June to September every year (Zhang et al., 2018; Chi et al., 2018). Although we have increased the storage capacity of Mangla reservoir to $39 \%$ but unfortunately, storage capacity has decreased up to $36 \%$ in Tarbela and 61\% in Chashma reservoir. Our underground water capacity is 50 MAF out of which $40 \%$ is not useful for irrigation. So, we are highly dependent on natural river flows being dammed and diverted by India (Kalair et al., 2019).

In Pakistan, mostly irrigations are applied to orchards using flood irrigation system which is considered subeconomical due to wastage of water and spreads soil borne fungal diseases. According to Philar (2019) excessive flood irrigations cause undesirable soil conditions together with poor soil structure and increases Phytophthora incidence. Additionally, the ability of roots to absorb ions is affected by these diseases; deficiency syndromes become common leading to an increased application of micronutrients which can increase soil toxicity.

According to another report, fungal and bacterial diseases are spreading in the orchards directly or indirectly in humid conditions where flood irrigation systems is practiced (Singh and Sharma, 2012). Kinnow fruit is vulnerable to diseases and insect pest attack. Cavalcante et al. (2012)stated that citrus trees with sufficient water and nutrients tolerate pest and stresses better, produce better yield consistently with better quality fruits compared with poorly managed irrigation and nutrient supply. Although for citrus growers, flood irrigation system is considered an easy way of applying irrigation water to the orchards but it does not pay good economic return by reducing fruit yield, fruit quality and longevity of the trees. Beside water losses, costly nutrients are also leached down from the root zone during flood irrigation. Under furrow irrigation system real water saving can be more for furrow crops or wider spaced crops such as orchards, vegetables, and maize. According to a report Nelson et al. (2013), using border flood (BFd) irrigation method saved about $36 \%$ of water compared with traditional flood (TFd) irrigation and this water savings is nearly equivalent to water saving in drip and microjet sprinkler system.

In flood irrigation system, water is applied in a huge amount that keeps the soil and stem in moist condition for a longer period therefore promotes the incidence of soil borne fungal diseases, and for some time soil remains dry due to longer intervals between the two irrigations particularly during summer season(Kumar, 2016). In both cases, the trees remain under stress condition that causes reduction in the yield and produces poor quality fruits. Furrow irrigation system is also a surface method of applying irrigation water to orchard through water channels prepared along both sides of the row of fruits trees. Water is applied in furrows that reach in the root zone of the tree through seepage. Turning flood irrigation into furrow irrigation can reduce loss of fertilizers and soil applied pesticides caused by leaching (Alva et al., 2006). This would minimize environmental contamination, and concurrently retain more fertilizer for citrus roots leading to improved yields.

An irrigation method capable of fulfilling the plant's water requirement, and simultaneously keeping the soil moisture within the desired limit during different phenological stages would ensure better production of citrus orchards on sustainable basis and prolong orchard's productive life (Pyle, 1985). According to the best of our knowledge, limited studies have been reported on furrow irrigation system particularly related to citrus orchards. Thus, considering the scarcity of water resources, we have conducted this study to devise the way of applying irrigation water that could improve the WUE and yield of Kinnow mandarin. By applying this method of irrigation, growers can supply good canal irrigation water to their plants during scarcity of water. In the same way, farmers have to no need to pump out unsuitable underground water for their orchard when availability of water is decreasing.

\section{MATERIALS AND METHODS \\ Experimental area and design}

The study was conducted at Citrus Research Institute, Sargodha ( $32^{\circ} 4^{\prime \prime}$ N and $72^{\circ} 40^{\prime}$ ' E) in Punjab, Pakistan on 
25 years old Kinnow mandarin trees grafted onto rough lemon rootstock cultivated on silt clay loam soil. The experiment was conducted for four years during 2011-15. A Kinnow block having an area of 0.41 ha was used for this study. The row to row and plant to plant distance was $6.1 \mathrm{~m}$. This Kinnow block was previously under flood irrigation system. The block was divided into two parts. Two different irrigation systems, furrow irrigation and flood irrigation systems were established in each block, separately. Furrows were made manually under the tree canopy of both sides of the tree row. The $\mathrm{V}$ shaped furrows were about $90 \mathrm{~cm}$ wide on upper side, $60 \mathrm{~cm}$ wide on bottom and depths of furrows were maintained as $15 \mathrm{~cm}$. Experiment was laid out according to randomized complete block design (RCBD). Three plants per treatment were used in this study and each treatment was replicated four times. A total of 24 trees having uniform age and canopy size were selected for data collection. One row from both blocks was kept as a buffer line to eliminate the error caused by seepage effect. Each block received an equal amount of fertilizer $(1000,500$, $500 \mathrm{~g}$ NPK per plant). Other cultural practices such as pruning (removal of disease and dead branches) and application of fungicides and insecticides were kept same for both plots to maintain the uniformity.

\section{Physiochemical properties of soil}

The soil texture of the experimental orchard was silt clay loam. EC and $\mathrm{pH}$ indicated that it was a normal but calcareous in nature. The phosphorus, potassium and DTPA extractable Zn contents were found in optimum range but $0 \mathrm{M} \%$ and $\mathrm{N} \%$ were in deficient range (Table 1 ).

\section{Installation of tensiometers and measurement of discharge}

Tensiometers were installed in each block at $30 \mathrm{~cm}$, $60 \mathrm{~cm}$, and $90 \mathrm{~cm}$ soil depth to monitor the moisture level in the soil. The irrigations were applied when tensiometer reading reached above 40 centibars (an average reading of tensiometers installed at 30 and 60 $\mathrm{cm}$ soil depth). A flume meter was used to measure the total quantity of water applied in furrow and flood irrigation system.

\section{Water Use Efficiency $\left(\mathrm{kg} \mathrm{m}^{-3}\right)$}

WUE was determined using the following formula; WUE $=\{$ Total yield (tons per ha) $/$ Total water used (mm)] X 100.

\section{Measurement of different fruit characters}

At fruit maturity, total fruit yield (kg tree $\left.{ }^{-1}\right)$ was determined by harvesting fruits from each tree. Fruit size (diameter) of one hundred fruits per tree was measured with vernier calliper at maturity stage. Ten fruits per tree were collected for measuring the average fruit weight (g per fruit) and further used for physicochemical analysis of the fruits. The juice from each fruit was extracted using a rotary citrus squeezer and filtered through $0.8 \mathrm{~mm}$ pore size sieve. By using a digital calibrated weighing balance, the filtered juice weight was measured in grams and juice percentage was calculated by the following formula (Lacey et al., 2009).

Juice percentage $=$ Juiceweight $(\mathrm{g}) /$ Fruitweight $\times 100$ The rag percentage was determined with this formula Rag percentage $=$ Fruitweight - (Juiceweight +

Peelweight)/fruitweight $\times 100$

TSS was determined by using a calibrated Atago Analog Refractometer and expressed as percentage of sucrose in an equivalent solution. The acidity was determined by titration with $0.1 \mathrm{~N} \mathrm{NaOH}$ using a known volume of representative sample of the fruit juice. Phenolphthalein was used as an indicator to check the persistent pink colour.

\section{Statistical analysis}

Four-year data were pooled and then subjected to analysis of variance (ANOVA) using Statistix version 8.1. Treatment means were compared by Fishers least significant difference (LSD) test at $\mathrm{P} \leq 0.05$. The data collected for nutrients concentration in soil and leaf tissue were compared using two sample $\mathrm{T}$ test.

\section{RESULTS}

Effect of furrow and flood irrigation system on fruit yield and physicochemical properties of Kinnow fruit

Furrow and flood irrigation systems apparently affected the yield and quality of Kinnow fruits. According to our results, numbers of fruits per tree and fruit yield (kg per tree) were improved with furrow irrigation system compared with flood irrigation system (Table 2). The average yield in furrow irrigation system was improved by up to $38.45 \%$ (43.50 $\mathrm{t} \mathrm{ha}^{-1}$ ) compared with flood system $\left(26.77 \mathrm{t} \mathrm{ha}{ }^{-1}\right)$. It was also observed that in furrow irrigation system yield was gradually improved annually and it was found maximum (55.33 $\mathrm{t} \mathrm{ha}^{-1}$ ) during 2014-15, 
however this trend was not observed for flood irrigation system.The juice percentage was also affected by the different irrigation systems.

The higher juice percentage was observed for the fruits obtained from plants that were irrigated using furrow irrigation system compared with flood irrigation system. However, no difference was observed for fruit diameter, peel percentage, rag percentage and TSS/acidity ratio of the fruits obtained from furrow \& flood irrigated Kinnow plants (Table 2).

Table 1. Fertility status of experimental area.

\begin{tabular}{lcccccccc}
\hline Soil depth $(\mathrm{cm})$ & $\mathrm{pH}$ & $\mathrm{EC}\left(\mathrm{dSm}^{-1}\right)$ & $\mathrm{OM} \%$ & $\mathrm{~N}(\%)$ & $\begin{array}{c}\text { Av. P } \\
(\mathrm{ppm})\end{array}$ & $\begin{array}{c}\text { Av. K } \\
(\mathrm{ppm})\end{array}$ & Zn (ppm) DTPA & Texture \\
\hline $0-15$ & 7.9 & 1.4 & 0.90 & 0.013 & 16.20 & 180 & 0.67 & Silt Clay Loam \\
$15-30$ & 8.1 & 1.2 & 0.62 & 0.012 & 10.10 & 75 & 0.32 & \\
$30-60$ & 8.0 & 0.9 & & & & & & \\
$60-90$ & 7.9 & 1.1 & & & & & & \\
$90-120$ & 8.0 & 0.9 & & & & & & \\
$120-150$ & 7.8 & 0.8 & & & & & & \\
\hline
\end{tabular}

$\mathrm{O} . \mathrm{M}=$ Organic Matter, $\mathrm{EC}=$ Electrical conductivity, $\mathrm{N}=$ Nitrogen, Av. $\mathrm{P}=$ Available Phosphorus, Av. $\mathrm{K}=$ Available Potassium, Zn (DTPA) = Extractable zinc through DTPA

Table 2. Effect of furrow and flood irrigation system on yield and quality of Kinnow mandarin.

\begin{tabular}{|c|c|c|c|c|c|c|c|}
\hline \multirow[t]{2}{*}{ Irrigation method } & \multirow{2}{*}{$\begin{array}{c}\text { Fruit yield } \\
\text { (kg plant-1) }\end{array}$} & \multirow{2}{*}{$\begin{array}{c}\text { Number of } \\
\text { (fruits plant }{ }^{-1} \text { ) }\end{array}$} & \multirow{2}{*}{$\begin{array}{l}\text { Fruit diameter } \\
\qquad(\mathrm{mm})\end{array}$} & \multirow[t]{2}{*}{ TSS/Acidity ratio } & \multirow{2}{*}{\multicolumn{3}{|c|}{$\begin{array}{r}\text { Peel } \\
\%)\end{array}$}} \\
\hline & & & & & & & \\
\hline$\overline{\text { Furrow irrigation system }}$ & $179.89^{\mathrm{A}}$ & $1153^{\mathrm{A}}$ & $69.11^{\mathrm{A}}$ & $16.66^{\mathrm{A}}$ & $21.02^{\mathrm{A}}$ & $30.79^{\mathrm{A}}$ & $48.38^{\mathrm{A}}$ \\
\hline Flood irrigation system & $110.61^{\text {в }}$ & $711^{\text {в }}$ & $67.54^{\mathrm{A}}$ & $16.35^{\mathrm{A}}$ & $22.45^{\mathrm{A}}$ & $31.14^{\mathrm{A}}$ & $46.31^{\text {в }}$ \\
\hline $\mathrm{CV}^{\mathrm{a}}$ & 19.87 & 117.22 & 2.91 & 0.48 & 2.37 & 1.70 & 1.37 \\
\hline
\end{tabular}

a Coefficient of variation. Means followed by the similar letters in the column do not differ significantly at P $\leq 0.05$ according to the Fishers Least Significant Difference test.

Total water consumption and numbers of irrigation Furrow irrigation system consumed $46 \%$ less average irrigation water per annum (240.50 $\mathrm{mm})$ compared with flood irrigation ( $446.53 \mathrm{~mm}$ ) and total amount of water used per year was also less $(948.95 \mathrm{~mm})$ in furrow irrigation system compared with flood irrigation system $(1,154.98)$ (Table 4). The total average numbers of irrigation per year were 24 for flood irrigation system however these were reduced to 15 when flood irrigation system was used. Average rainfall received during the four cropping seasons was $708 \mathrm{~mm}$, and the highest amount of rainfall $(1,874 \mathrm{~mm})$ was received during 2014-15 (Table 4).

\section{Water Use Efficiency (WUE) and water saving} In furrow irrigation system, average WUE for four cropping seasons was higher (4.58 $\left.\mathrm{kg} \mathrm{m}^{-3}\right)$ compared with flood irrigation system $\left(2.34 \mathrm{~kg} \mathrm{~m}^{-3}\right)$. However, the highest WUE ( $\left.8.39 \mathrm{~kg} \mathrm{~m}^{-3}\right)$ in furrow irrigation system was achieved during 2013-14 and this was minimum (2.77 $\mathrm{kg} \mathrm{m}^{-3}$ ) during 2014-15. In furrow irrigation system, average water saving was $46.14 \%$, and maximum water saving of $49.37 \%$ and $47.70 \%$ was observed during 2011-12 and 2014-15, respectively compared with flood irrigation system (Table 3).

\section{Effect of irrigation methods on $\mathrm{N}, \mathrm{P}, \mathrm{K}$ and $\mathrm{Zn}$ contents in soil and plant's tissue}

We observed a considerable difference for concentration of nutrients such as $\mathrm{N}, \mathrm{P}, \mathrm{K}$, and $\mathrm{Zn}$ (ppm) in the leaves of Kinnow plants irrigated using furrow and flood irrigation system. Higher mean values were observed for $\mathrm{N}(3.21 \%), \mathrm{P}(0.13 \%), \mathrm{K}(1.39 \%)$ and $\mathrm{Zn}(29.6 \%)$ in the leaves of trees that were irrigated by furrow irrigation system compared with flood irrigation system (Table 5). Soil available $\mathrm{K}$ (241.67 ppm) was significantly higher under tree canopy of furrow irrigated trees while total N\%, available P (ppm) and DTPA extractable Zn (ppm) were not affected by these irrigation systems. 
Table 3. Irrigation water used by furrow and flood irrigation systems during 4 years of experimental period (2011-14).

\begin{tabular}{|c|c|c|c|c|c|c|c|}
\hline \multirow[t]{3}{*}{ Year } & \multicolumn{3}{|c|}{ Furrow Irrigation } & \multicolumn{2}{|c|}{ Flood Irrigation } & \multirow[b]{2}{*}{$\begin{array}{l}\text { Total } \\
\text { water }\end{array}$} & \multirow[b]{2}{*}{ Rainfall } \\
\hline & \multirow[t]{2}{*}{$\begin{array}{c}\text { No. of } \\
\text { irrigation }\end{array}$} & $\begin{array}{c}\text { Irrigation } \\
\text { water }\end{array}$ & Total water & \multirow[t]{2}{*}{$\begin{array}{c}\text { No. of } \\
\text { irrigation }\end{array}$} & $\begin{array}{c}\text { Irrigation } \\
\text { water }\end{array}$ & & \\
\hline & & \multicolumn{2}{|c|}{$\mathrm{mm}$} & & & $\mathrm{mm}$ & \\
\hline 2011-12 & 26 & 311.74 & 535.06 & 19 & 615.69 & 839.01 & 223.32 \\
\hline $2012-13$ & 18 & 248.59 & 665.59 & 14 & 465.47 & 882.47 & 417 \\
\hline 2013-14 & 23 & 276.27 & 595.77 & 17 & 469.67 & 789.17 & 319.5 \\
\hline $2014-15$ & 11 & 125.40 & 1999.40 & 10 & 235.28 & 2109.28 & 1874 \\
\hline Average & 24 & 240.50 & 948.95 & 15 & 446.53 & 1154.98 & 708.455 \\
\hline
\end{tabular}

Total water $=$ irrigation water + rainfall.

Irrigation water applied to each plot was adjusted according to rainfall contribution and it was calculated lower in 2014-15 where ample amount of rainfall was received during the year.

Table 4. Effect of furrow and flood irrigation system on yield and water use efficiency (WUE) of Kinnow mandarin.

\begin{tabular}{lccccc}
\hline Year & Yield $\left(\mathrm{t} \mathrm{ha}^{-1}\right)$ & WUE $\left(\mathrm{kg} \mathrm{m}^{-3}\right)$ & Yield $\left(\mathrm{t} \mathrm{ha}^{-1}\right)$ & WUE $\left(\mathrm{kg} \mathrm{m}^{-3}\right)$ & $\begin{array}{c}\text { Water saving (\%) } \\
\text { in furrow irrigation system }\end{array}$ \\
\cline { 2 - 5 } $2011-12$ & Furrow irrigation system & \multicolumn{2}{c}{ Flood irrigation system } & \\
\cline { 2 - 5 } $2012-13$ & 29.71 & 5.55 & 30.07 & 3.70 & 49.37 \\
$2013-14$ & 48.97 & 5.86 & 27.28 & 3.21 & 46.59 \\
$2014-15$ & 55.99 & 8.39 & 22.55 & 2.84 & 41.18 \\
\hline Average & 43.50 & 2.77 & 27.20 & 1.29 & 46.70 \\
\hline
\end{tabular}

Table 5. Effect of irrigation system on nutrients concentration in soil and plant's tissue.

\begin{tabular}{lcccccccc}
\hline & \multicolumn{3}{c}{ Concentration in Soil } & \multicolumn{4}{c}{ Concentration in the leaf tissues } \\
\hline & $\mathrm{N}(\%)$ & Av. P (ppm) & Av. K (ppm) & Zn (ppm)DTPA & $\mathrm{N}(\%)$ & $\mathrm{P}(\%)$ & $\mathrm{K}(\%)$ & Zn (ppm) \\
\hline Furrow & 0.015 & 14.04 & 241.67 & 0.7567 & 3.21 & 0.13 & 1.39 & 29.6 \\
\hline Flood & 0.014 & 13.86 & 165.83 & 0.7667 & 2.44 & 0.078 & 0.73 & 20.42 \\
\hline $\mathrm{P}$ & $0.3208^{* 1}$ & $0.8732^{* 1}$ & $00^{*}$ & $0.8732^{* 1}$ & $00^{*}$ & $00^{*}$ & $00^{*}$ & $00^{*}$ \\
\hline F & 1.27 & 1.93 & 1.78 & 1.12 & 1.84 & 3.4 & 7.86 & 3.95 \\
\hline
\end{tabular}

*Mean values differ at $P \leq 0.05$ by two sample T test*1Mean values do not differ at $P \leq 0.05$

Table 6. Combined ANOVA.

\begin{tabular}{|c|c|c|c|c|c|c|c|}
\hline SOV & $\begin{array}{l}\text { Number of } \\
\text { fruits tree }-1\end{array}$ & Fruit yield & Fruit dia. & Juice \% & Peel \% & Rag \% & $\begin{array}{l}\text { TSS/Acidity } \\
\text { ratio }\end{array}$ \\
\hline Treatment & $1567649^{* *}$ & $38395.1^{* *}$ & $19.625^{N S}$ & $34.3258^{* *}$ & $0.959^{\mathrm{NS}}$ & $16.363^{\mathrm{NS}}$ & $0.7784^{\mathrm{NS}}$ \\
\hline Year & $174485^{* *}$ & $3187.2^{* *}$ & $19.5609^{\mathrm{NS}}$ & $16.6116^{*}$ & $114.915^{* *}$ & $117.119^{* *}$ & $59.7135^{* *}$ \\
\hline Treat*Year & $149806^{* *}$ & $6375.2^{* *}$ & $7.7912^{\mathrm{NS}}$ & $3.0357^{\mathrm{NS}}$ & $25.193^{*}$ & 21.468 NS & $4.4844^{* *}$ \\
\hline
\end{tabular}

${ }^{* *}$ Highly significant at $P \leq 0.05$, *Significant at $P \leq 0.05$, NS: Non-significant

\section{DISCUSSION}

Furrow irrigations improves the yield and physicochemical properties of the Kinnow fruit

Irrigation systems affect the fruit yield and quality of the fruit crops. According to the results of this four years study, number of fruits per tree and fruit yield was increased using furrow irrigation system compared with flood irrigation (Table 2). In furrow irrigation system, frequent application of irrigation water maintains the adequate moisture level in the active root zone of the trees and reduces leaching of nutrients towards the deeper soil layers. Another factor that increases fruit yield in furrow irrigation is the less or minimum disturbance to plant's roots that improves tree health and lead to good fruit yield compared with flood irrigation system (Granatstein and Sánchez, 2009). In flood irrigation system, huge amount of water is applied to the entire field that results in excessive growth of 
weeds and to keep the field clean, repeated ploughing become necessary. This practice makes favorable condition for different soil borne diseases and eventually may lead to the tree decline (Steinmaus, 2014). Fruit trees require optimum soil moisture for fruit setting and rapid cell division and cell enlargement of developing fruits. A regular supply of water with short interval is possible in furrow irrigation system compared with flood irrigation system. In flood irrigation a large amount of water is applied at the time of irrigation and the interval between two irrigation is more compared with furrow irrigation system(Hutton et al., 2007). Thus, furrow irrigation maintains the regular supply of moisture compared with flood irrigation leading towards improved yield (Raza, 2016). Additionally, furrow irrigation improved the concentration of essential nutrients such as N, P, K and Zn (Table 5) that seems involved in better yield under furrow irrigation compared with flood irrigation. The yield per plant was gradually increased because of continuous improvement in the health of tree grown under furrow irrigation system but this trend was not observed for the plants grown under flood irrigation system. This can be attributed to the poor health of the trees and losses of nutrients from the soil through leaching. The juice percentage of Kinnow fruit was found higher (48.38\%) for furrow irrigation system due to optimum supply of moisture and juice percentage was reduced to $46.31 \%$ for flood irrigation system. Similar finding was reported by Pérez-Pérez et al. (2009), they observe that fruit quality such as total soluble solids (TSS) and titratable acidity (TA) are increased and juice percentage is decreased by deficient irrigation without altering the final maturity index.

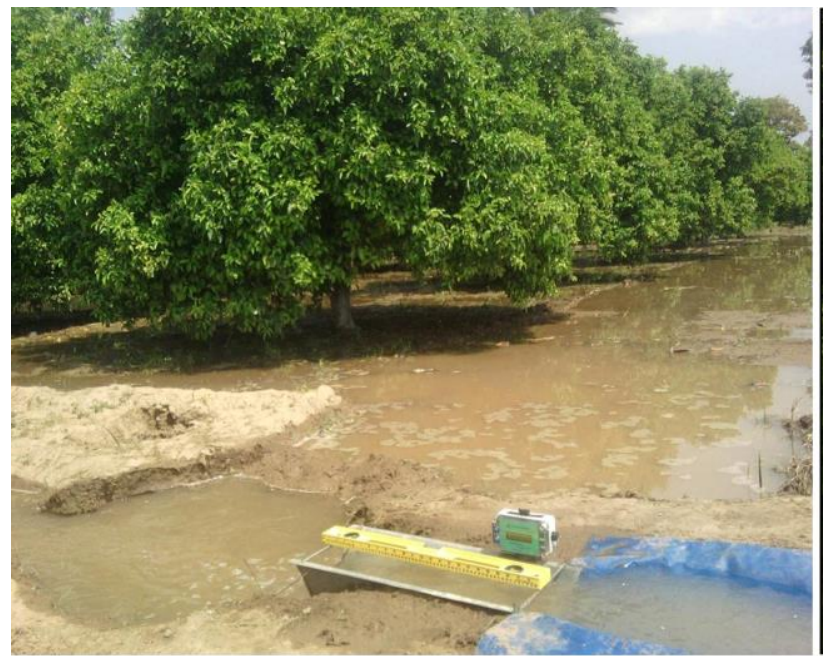

Flood Irrigation System

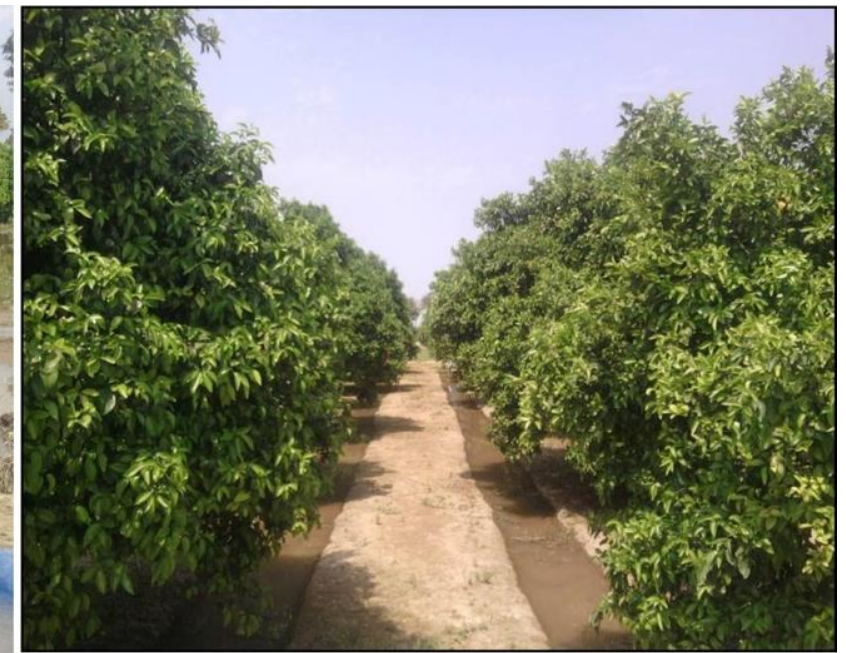

Furrow Irrigation System

Figure 1.Kinnow trees growing under flood and furrow irrigation system.

Total water consumption and numbers of irrigations applied in different irrigation systems

Water scarcity is a widespread problem across the world. A large amount of water is utilized for the irrigation of crops. Thus, the research work related with the efficient methods of irrigation is gaining popularity. In our study, furrow irrigation system consumed less average water $(240.50 \mathrm{~mm})$ compared with flood irrigation $(446.53 \mathrm{~mm})$. Similarly, the total amount of water used for the irrigation per year in furrow irrigation system was $948.95 \mathrm{~mm}$, however in flood irrigation system this amount of water was increased to
$1154.98 \mathrm{~mm}$ (Table 3). According to a report, water consumption was higher in flood irrigation compared with furrow irrigation for sweet orange (Citrus sinensis Obseck.) without compromising the yield (Ali, 2016). In this study for furrow irrigation water was applied along the sides of tree's canopy and the remaining area was kept dry; however, for flood irrigation system entire area was flooded without targeting the trees or root zone of the growing tress. Because of this, water consumption in furrow irrigation system was lower compared with flood irrigation system. According to Kang et al. (2002), fixed partial root zone irrigation and 
alternate partial root zone irrigation reduced total irrigation $52 \%$ and $23 \%$ and water used by $28 \%$ and $12 \%$, respectively compared with conventional flood irrigation system. In this study although number of irrigations were more for furrow irrigation system because water was applied with short intervals but in lesser amount compared with water used for flood irrigation. So, average higher numbers of irrigations (24) were observed for furrow irrigation system compared with in flood irrigation system (15).

\section{Water use efficiency (WUE) and water saving percentage}

Efficient irrigation methods such as furrow irrigation ensure higher WUE. Biologists are working to achieve maximum yield with minimum input of water and fertilizers. Poor irrigation practices reduce WUE and fertilizers use efficiency. According to Abdel-Aziz et al. (2013)surface irrigation method such as Double Railway improved WUE of Valencia orange by up to $38.90 \%$ under sandy loam condition compared with Double Drip Lines. In our study, furrow irrigation system saved water by up to $46.14 \%$ compared with flood irrigation system, because in furrow irrigation system water is applied only into the furrows under the tree canopy while the remaining area kept completely dry. However, in flood system too much water is applied irrespective of root zone of the tree. The trees in furrow systems produce maximum yield and have better WUE because of frequent supply of irrigation water. We also observed higher average WUE for four cropping seasons $(4.58 \mathrm{~kg}$ $\mathrm{m}^{-3}$ ) for furrow irrigation system and lower $\left(2.34 \mathrm{~kg} \mathrm{~m}^{-3}\right)$ for flood irrigation system (Table 4).

In 2013-14, the highest WUE (8.39 $\mathrm{kg} \mathrm{m}^{-3}$ ) was observed for furrow irrigation system while it was minimum (2.77 $\mathrm{kg} \mathrm{m}$-3) during 2014-15. The lower WUE in 2014-15 may be attributed to the high input of water that was $1999.40 \mathrm{~mm}$ including a high rainfall $(1874 \mathrm{~mm})$ (Table 3 ). The highest rainfall received during 2014-15 could not be considered beneficial for orchards because most part of this rainfall occurred in two months (July to August, 2014).According to a field survey conducted by Elomari et al. (2016) in Morocco to diagnose the current situation of the water efficiency in citrus irrigation, they found that water productivity was $1.20 \mathrm{~kg} \mathrm{~m}-3$ for surface irrigation and $3.80 \mathrm{~kg} \mathrm{~m}^{-3}$ for drip irrigation. In addition, by using monitoring tool agronomic water use efficiency showed an increase of $24.50 \%\left(4.26 \mathrm{~kg} \mathrm{~m}^{-3}\right)$.

\section{Effect of irrigation systems on nutrients concentration}

Irrigation has great effect on fertilizers use efficiency, fruit yield and quality. Faulty irrigation practices deteriorate fruit quality by reducing nutrients uptake from the soil (Quiñones et al., 2007).The same results were observed in our study(Table 5), the higher nutrient contents (N, P, K and Zn) in leaf 'tissue of trees grown under furrow irrigation systems were found compared with trees under flood irrigation system. Improved irrigation practices provide maximum nutrient uptake and minimize nutrient leaching (Shirgure and Srivastava, 2013). Global meta-analysis for citrus yields, WUE and NUE was conducted using 1009 observations from 55 studies conducted in 11 countries, and it was estimated that reducing over-optimal irrigation to optimal irrigation may increase citrus yield by $20 \%$, WUE by $30 \%$ and NUE by $15 \%(Q i n$ et al., 2016). Our study proved that soil available potash was higher in furrow irrigated plots because of good irrigation practice that reduced nutrient leaching. Quiñones et al. (2007) and Nelson et al. (2013) observed that flood irrigation practices in citrus tree resulted in increased loss of $\mathrm{NO}_{3}-$ $\mathrm{N}$ as $\mathrm{N}$ migrated down the soil profile and outside of the effective uptake region by citrus tree roots compared with other water conserving irrigation practices. Because border flood(BFd) irrigation lowers the time of application to sustain a $10-\mathrm{cm}$ water application, this can minimize water loss to the non-root zone area of the field and localizes fertilizers effectively in the rooting depth of the tree.

\section{REFERENCES}

Abdel-Aziz, R., K. Fatma and M. Ibrahim. 2013. Evaluation of some Modified Flood Irrigation Methods on Growth and Fruit Quality of Valencia Orange Trees under Sandy Soil Conditions. Egyptian Journal of Horticulture, 40: 227-45.

Ali, W., Khurshid, T., Giddings, J. and Nabi, G. 2016. The effect of furrow and flood irrigation systems on water use efficiency and yield of sweet orange orchards in Pakistan. . Acta Hortic. 1128: 151-54.

Alva, A., S. Paramasivam, A. Fares, J. Delgado, D. Mattos Jr and K. Sajwan. 2006. Nitrogen and irrigation management practices to improve nitrogen uptake efficiency and minimize leaching losses. Journal of Crop Improvement, 15: 369-420. 
Cavalcante, Í. H. L., L. F. Cavalcante, J. M. de Sousa Miranda and A. B. G. Martins. 2012. Physical and chemical characteristics of tropical and nonconventional fruits. In, Food industrial processesmethods and equipment IntechOpen.

Chi, Z., Xiaoxian Chen, Yu Li, W. Ding and G. Fu. 2018. Water energy food nexus: Concepts, questions and methodologies. Journal of Cleaner Production, 195: 625-39.

Elomari, H., M. Fallah and A. Elmousadik. 2016. Effect of Irrigation Methods on Water Use Efficiency Applied to Citrus Crop in the Souss Region (Morocco) in the Context of Climate Change. International Journal of Agricultural and Biosystems Engineering, 9: 1308-13.

Granatstein, D. and E. Sánchez. 2009. Research knowledge and needs for orchard floor management in organic tree fruit systems. International journal of fruit science, 9: 257-81.

Hutton, R., J. Landsberg and B. Sutton. 2007. Timing irrigation to suit citrus phenology: a means of reducing water use without compromising fruit yield and quality? Australian Journal of Experimental Agriculture, 47: 71-80.

Kalair, A. R., N. Abas, E. Kalair and N. Khan. 2019. Water, energy and food nexus of Indus Water Treaty: Water governance. Water-Energy Nexus.

Kang, S., X. Hu, I. Goodwin and P. Jerie. 2002. Soil water distribution, water use, and yield response to partial root zone drying under a shallow groundwater table condition in a pear orchard. Scientia Horticulturae, 92: 277-91.

Kumar, M. D. 2016. Water saving and yield enhancing micro irrigation technologies in India: Theory and practice. In, Micro irrigation systems in India Springer.

Lacey, K., N. Hancock and H. Ramsey. 2009. Measuring internal maturity of citrusDepartment of Agriculture and Food.

Nawaz, U., S. Shahid, R. Ahmad, M. U. Ibrahim, A. Wajid, A. Manan and M. Qureshi. 2016. Indus Basin Irrigation System and climatic trends regarding glacial regimes and water runoff. J. Environ. J. Agric. Sci, 9: 28-36.

Nelson, S. D., J. M. Enciso, H. Perea, M. Sétamou, L. Beniken, M. Young and C. F. Williams. 2013.
Alternative flood irrigation strategies that improve water conservation in citrus. Subtropical Plant Science, 65: 15-23.2013.

Pérez-Pérez, J., J. Robles and P. Botía. 2009. Influence of deficit irrigation in phase III of fruit growth on fruit quality in 'lane late'sweet orange. Agricultural Water Management, 96: 969-74.

Philar, U. B. 2019. Holistic, cost effective method for management of huang long bing (HLB), phytophthora gummosis, asian citrus psyllid and other serious infestations in citrus and other cropsGoogle Patents.

Pyle, K. 1985. An appraisal of micro-irrigation for use in citrus with an emphasis on drip irrigation. Citrus Sub-tropical Fruit Journal, 61: 4-7.

Qin, W., F. B. Assinck, M. Heinen and O. Oenema. 2016. Water and nitrogen use efficiencies in citrus production: A meta-analysis. Agriculture, ecosystems \& environment, 222: 103-11.

Quiñones, A., B. Martínez-Alcántara and F. Legaz. 2007. Influence of irrigation system and fertilization management on seasonal distribution of $\mathrm{N}$ in the soil profile and on $\mathrm{N}$-uptake by citrus trees. Agriculture, ecosystems \& environment, 122: 399409.

Raza, A., Khan, A.R., Rehman, A., Hayat, A., Zaka, M.A. and Khurshid,T. 2016. Comparison of furrow and flood irrigation systems in 'Kinnow' mandarin under an Australian aid program. Acta Horticulture. 1128: 203-06.

Shirgure, P. and A. Srivastava. 2013. Nutrient-water interaction in citrus: recent developments. Agricultural Advances, 2: 224-36.

Singh, S. and N. Sharma. 2012. Research paper on drip irrigation management using wireless sensors. International Journal of Computer Networks and Wireless Communications, 2: 461-64.

Steinmaus, S. J. 2014. I entire citrus orchard floor (fig. 16.1). Weeds are. Citrus Production Manual, 3539: 239.

Zhang, X., H. Li., Z. D. Deng, C. Ringler, Y. Gao, M. I. Hejazi and L. R. Leung. 2018. Impacts of climate change, policy and Water-Energy-Food nexus on hydropower development. Renewable Energy, 116: 827-34. 
Publisher's note: EScience Press remains neutral with regard to jurisdictional claims in published maps and institutional affiliations.

(c)

Open Access This article is licensed under a Creative Commons Attribution 4.0 International License, which permits use, sharing, adaptation, distribution and reproduction in any medium or format, as long as you give appropriate credit to the original author(s) and the source, provide a link to the Creative Commons license and indicate if changes were made. The images or other third-party material in this article are included in the article's Creative Commons license, unless indicated otherwise in a credit line to the material. If material is not included in the article's Creative Commons license and your intended use is not permitted by statutory regulation or exceeds the permitted use, you will need to obtain permission directly from the copyright holder. To view a copy of this license, visit http://creativecommons.org/licenses/by/4.0/. 